\title{
CONDITIONED BEHAVIOR AMONG TERMITES (ISOPTERA)
}

\author{
By Alfred E. Emerson \\ University of Chicago
}

At the present time, no adequate observation indicating that the behavior of termites may be conditioned has been recorded. In several instances, so-called "intelligent" behavior of termites has been described or assumed (Bugnion, 1927; Hingston, 1929, 1932), but in none of these cases is it clearly shown that a termite behaves differently in the same situation before and after an experience. In as much as conditioned responses have been adequately demonstrated in various insects including ants, bees and cockroaches, it seems entirely possible that termites also are capable of learning, but experiments with rigid control have not been performed on termites with positive results. Julius F. Bosen has performed preliminary experiments with a simple maze similar to that used successfully by Gates and Allee (1933) for cockroaches. No indication of conditioning was detected, possibly owing to the fact that blind worker termites were used. The reward was a relatively moist chamber to which the termites reacted positively.

The following observations were made three years ago on a captive colony of Reticulitermes arenincola Goellner collected at Miller, Indiana, in the Lake Michigan sand dunes. Publication was delayed in the hope that further observations and experiments might bring more data to bear upon the problem, but this hope has not materialized.

The captive colony, containing many workers, several soldiers, several nymphs, two mature second form queens and one mature third form queen resided in apparent harmony in a glass dish with a ground glass cover for a month. 
On August 15, 1930, one of the second form queens and the third form queen were noticed jerking themselves violently and exhibiting great agitation. When they came in contact with each other they fought vigorously. Upon separating they remained excited, jerking themselves in the manner characteristic of all disturbed termites. Workers often attempted to lick these queens, at no time showing hostility to them during the conflict. The other second form queen was not involved in the fight in any way. The fighting queens continued the combat whenever they came into chance contact after intervals of separation, each seeming to be equally belligerent. During a half hour they fought and separated ten times. In the final encounter, the second form queen lost a leg and the third form queen was seriously bitten on the under side of the head. After a short time, the queens separated and the workers and nymphs immediately attacked the third form queen, biting and chewing it for a half hour until it was quite weak. The workers also attempted to bite the injured leg stump of the second form queen, but she managed to protect herself from serious injury by violently jerking. Other workers, busy with nest repair work in close vicinity to the injured queens, were not observed paying any attention to these events.

The termite workers and winged nymphs attacking the third form queen bit holes in her abdomen and head and seemed to give as much attention to all parts of her as they did to the injured parts. At any given moment seven or eight workers were eating this queen. The second form queen was licked and massaged by the workers and after about a half hour, the injured leg received no special notice.

The fight was first observed at about 12 noon. At 2 P. M. the third form queen had been decapitated and two separate groups of termites were eating the head and body. The second form queen at this time was quiet and several workers were licking her with no manifest hostile actions. At 3 P. M. the third form queen had been entirely eaten and the second form queen was quiet and in good condition. Six days later this second form queen was still alive and evidently healthy. The other second form queen which 
had taken no part in the fight was also still alive and well.

This observation does not readily fit into the class of inherited instinctive behavior. If either or both queens had had any characteristic which would stimulate general hostile action, one would assume that the workers and soldiers would have shown hostility and possibly the third queen would also have been involved in the fight. General hostile action toward a strange termite or other insect often has been observed, but in such cases any termite coming into contact with the stranger will attack it. These two queens, however, showed hostility only to each other (indicating an interesting ability to recognize each other) and no other termites exhibited hostility to either of them until they were badly injured, when the cannibalistic activities well known in termite colonies appeared. The observation is interesting as an example of naturally induced cannibalism.

The presence of the third queen gives a fairly good control against the possibility that this antagonistic behavior between the queens was a caste pattern. The fact that all three of the queens lived together in harmony before the fight occurred also offers a fair control against the possibility that this hostile action was induced through hereditary caste differences. Field observations summarized in table I indicate no evidence of common antagonism between the different reproductive castes or individuals, which are often found living together harmoniously in the same nest.

Possibly one might explain such action as inherited individual differences occurring at a certain stage in the life cycle. It is also possible that the antagonistic behavior was in some way induced by an internal physiological influence not present at the same time in the third queen.

Although it must be admitted that these interpretations are possible, it seems to the writer that the mutual hostility displayed by these queens is best explained on the basis of a conditioned response. The nature of the experience which may have conditioned these queens to such individualistic action, however, remains unknown. 


\section{TABLE I}

Records of reproductive castes found living together in the same nest. Numbers refer to the number of each caste collected.

\begin{tabular}{|c|c|c|c|c|c|}
\hline & $\begin{array}{c}1 \text { st form } \\
\text { king }\end{array}$ & $\begin{array}{c}\text { 1st form } \\
\text { queen }\end{array}$ & $\begin{array}{l}2 \mathrm{~d} \text { form } \\
\text { king }\end{array}$ & $\begin{array}{l}2 \mathrm{~d} \text { form } \\
\text { queen }\end{array}$ & $\begin{array}{l}3 \mathrm{~d} \text { form } \\
\text { queen }\end{array}$ \\
\hline $\begin{array}{l}\text { Reticulitermes flavipes } \\
\text { (Kollar). Cold Spring } \\
\text { Harbor, N. Y. }\end{array}$ & - & - & 113 & 126 & - \\
\hline $\begin{array}{l}\text { Reticulitermes flavipes } \\
\text { (Kollar). See Banks and } \\
\text { Snyder (1920) }\end{array}$ & 1 & - & - & $X$ & - \\
\hline $\begin{array}{l}\text { Reticulitermes } \\
\text { arenincola Goellner } \\
\text { Miller, Indiana }\end{array}$ & - & - & - & 2 & 1 \\
\hline $\begin{array}{l}\text { Rhinotermes (R.) } \\
\text { tenebrosus Emerson } \\
\text { Kartabo, Br. Guiana }\end{array}$ & - & - & - & 1 & 1 \\
\hline $\begin{array}{l}\text { Armitermes (A.) } \\
\text { albidus (Hagen) } \\
\text { Kartabo, Br. Guiana }\end{array}$ & - & 1 & 1 & 2 & - \\
\hline $\begin{array}{l}\text { Armitermes (A.) } \\
\text { percutiens Emerson } \\
\text { Kartabo, Br. Guiana }\end{array}$ & - & - & 2 & 78 & - \\
\hline $\begin{array}{l}\text { Armitermes (A.) } \\
\text { percutiens Emerson } \\
\text { Kartabo, Br. Guiana }\end{array}$ & 1 & - & - & 7 & - \\
\hline $\begin{array}{l}\text { Armitermes (A.) } \\
\text { minutus Emerson } \\
\text { Kartabo, Br. Guiana }\end{array}$ & 1 & - & - & 35 & - \\
\hline $\begin{array}{l}\text { Nasutitermes (N.) } \\
\text { costalis (Holmgren) } \\
\text { Grenada, West Indies }\end{array}$ & 30 & 46 & - & - & - \\
\hline $\begin{array}{l}\text { Nasutitermes (Subulitermes) } \\
\text { parvellus (Silvestri) } \\
\text { Kartabo, Br. Guiana }\end{array}$ & 1 & - & - & 5 & - \\
\hline
\end{tabular}

\section{SUMMARY}

No valid case of a conditioned response in termites has been reported. The behavior described in the literature can readily be interpreted as the result of hereditary influences and thus may be referred to as instinctive. A fight between two queens in a captive colony in the presence of workers, nymphs, soldiers and another queen, none of which exhibited any antagonistic response to either of the 
fighting queens, may be interpreted as a conditioned response leading to individualistic action.

\section{Literature Cited}

Banks, N., and T. E. Snyder. 1920. A Revision of the Nearctic Termites. U. S. Nat. Mus. Bull. 108.

Bugnion, E. 1927. The Origin of Instinct: A Study of the War between the Ants and the Termites. Translated by C. K. Ogden. Psyche Monographs No. 1. Kegan Paul, Trench, Trubner \& Co. London.

Gates, Mary F., and W. C. Allee. 1933. Conditioned Behavior of Isolated and Grouped Cockroaches on a Simple Maze. Journ. Comp. Psychology, 15:331-358.

Hingston, R. W. G. 1929. Instinct and Intelligence. The Macmillan Company. New York.

Forest. Longmans, Green \& Co. New York. 

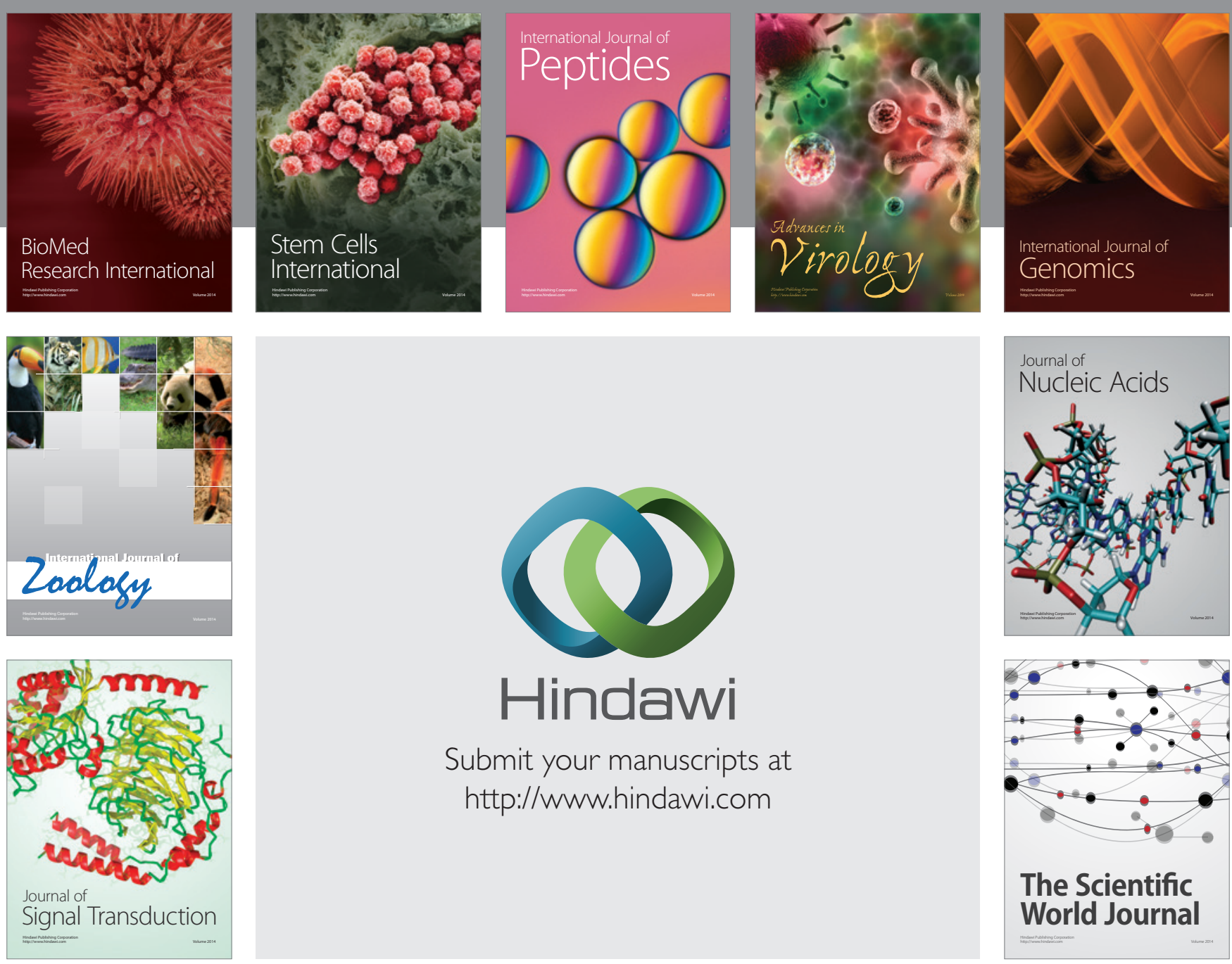

Submit your manuscripts at

http://www.hindawi.com
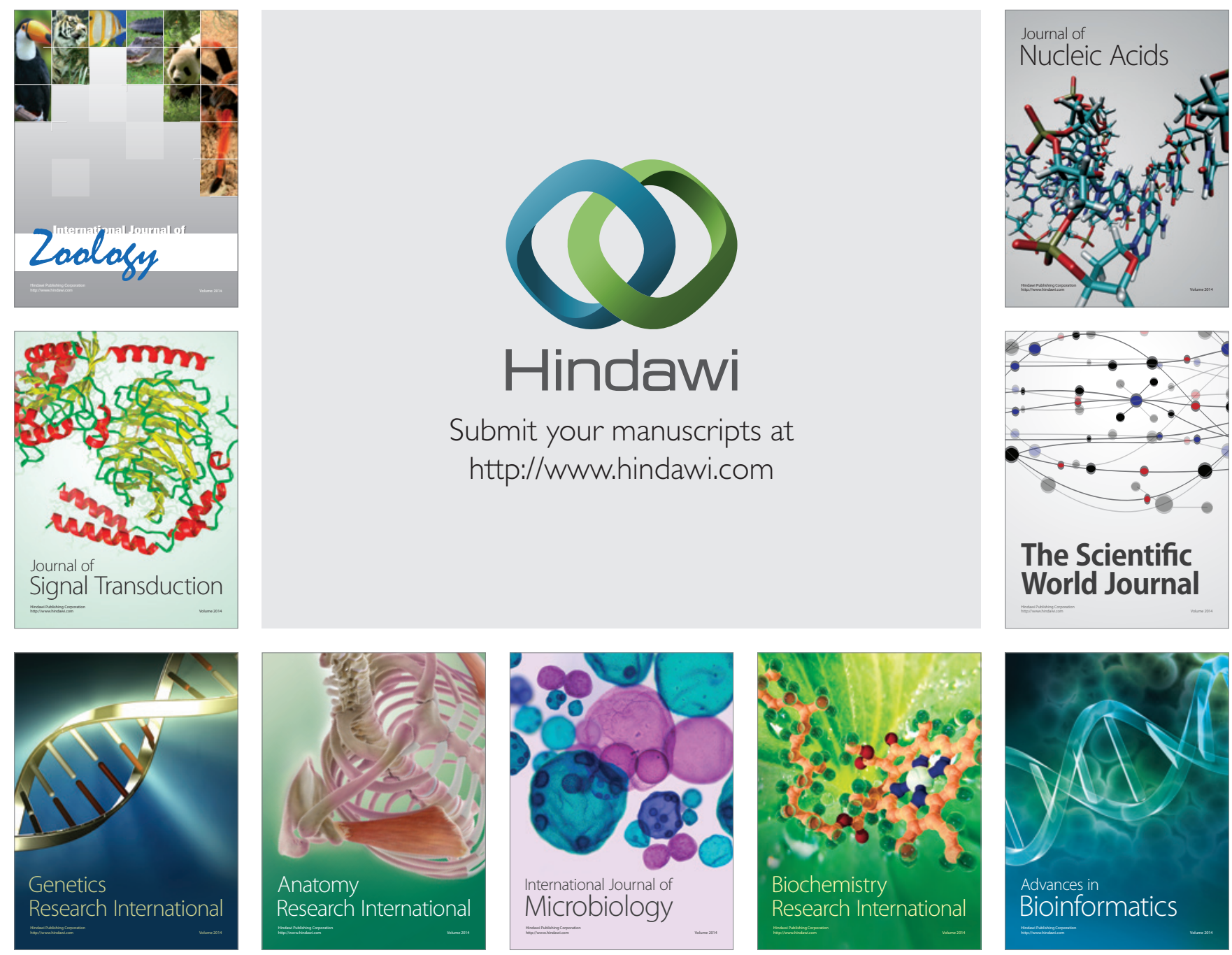

The Scientific World Journal
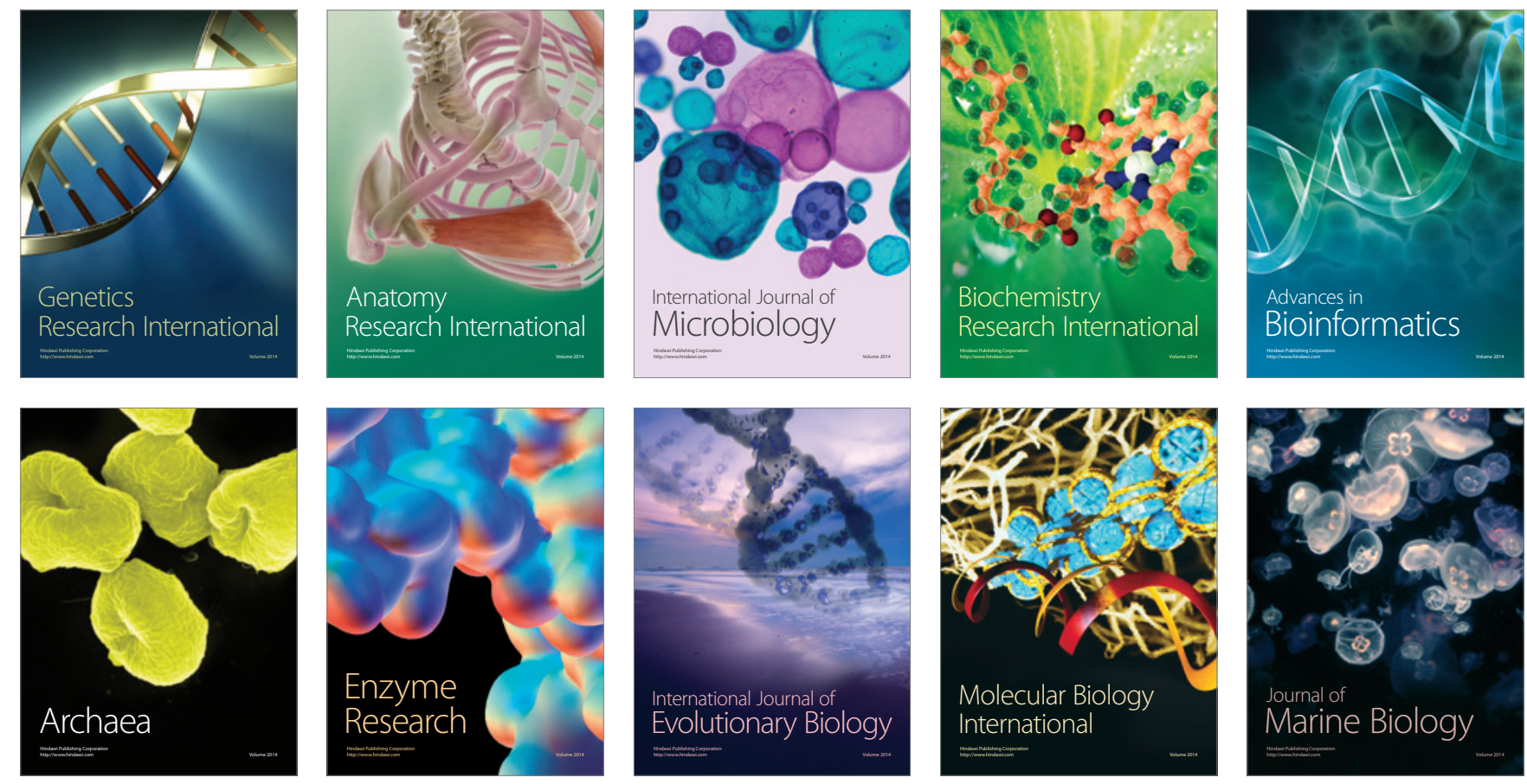